\title{
Extrathyroidal congenital defects in children with congenital hypothyroidism - observations from a single paediatric centre in Central Europe with a review of literature
}

Występowanie pozatarczycowych wad wrodzonych u dzieci z wrodzoną niedoczynnością tarczycy - obserwacje pojedynczego ośrodka pediatrycznego w Europie Centralnej z przeglądem piśmiennictwa

${ }^{1}$ Anna Wędrychowicz, ${ }^{1}$ Aleksandra Furtak, ${ }^{2}$ Anna Prośniak, ${ }^{2}$ Magdalena Żuberek, ${ }^{2}$ Maria Szczerkowska, ${ }^{2}$ Peter Pacut, ${ }^{3,4}$ Dorota Lemańska, ${ }^{4}$ Aleksandra Słuszniak, ${ }^{1}$ Jerzy B. Starzyk

${ }^{1}$ Institute of Paediatrics, Department of Children and Youth Endocrinology, Jagiellonian University Medical College, Krakow, Poland

${ }^{2}$ Scientific Students' Group at Department of Children and Youth Endocrinology, Jagiellonian University Medical College, Krakow, Poland

${ }^{3}$ Department of Dietetics, Andrzej Frycz Modrzewski Krakow University, Poland

${ }^{4}$ Laboratory of Screening and Inborn Errors of Metabolism, University Children's Hospital, Krakow, Poland

\begin{abstract}
Introduction: Patients with congenital hypothyroidism $(\mathrm{CH})$ can have an increased risk of occurrence of extrathyroidal defects compared to the general population, which could influence their development. The abnormalities occur mainly in organ systems whose development and function is dependent on genes that are also responsible for proper organogenesis of the thyroid gland and thyroid hormone synthesis.

Aim of the study: The aim of the study was to evaluate the frequency of extrathyroidal defects in $\mathrm{CH}$ patients, taking into consideration the cause of this co-occurrence and the role of genetic tests.

Material and methods: The study included 54 newborns with positive screening test for $\mathrm{CH}$ based on elevated TSH level, in the years 2010-2017, from South-Eastern Poland. The data was retrieved retrospectively from patients' medical records.

Results: Twenty of 54 newborns with $\mathrm{CH}(37 \%)$ had congenital defects of other organs. In 10 (18.5\%) cardiac defects were found, in $5(9.25 \%)$ abnormal symptoms of the respiratory system, 7 (12.96\%) had abnormalities of the gastrointestinal system, five (9.25\%) had genitourinary abnormalities, 3 (5.55\%) had abnormalities of the nervous system, and 6 (11.1\%) had musculoskeletal abnormalities.

Conclusions: The analysis of our data and current literature suggests that genetic factors play the most important role in the development of extrathyroidal abnormalities in newborns with $\mathrm{CH}$. Identifying the mutation causing $\mathrm{CH}$, the potential defects that can accompany newborns with $\mathrm{CH}$, screening could be offered for these patients in order to obtain an earlier diagnosis and implement early and appropriate treatment.
\end{abstract}

Key words:

congenital hypothyroidism, congenital defects, mutations.

\section{Streszczenie}

Wprowadzenie: Pacjenci z wrodzoną niedoczynnością tarczycy (congenital hypothyroidism - $\mathrm{CH}$ ) mają większe niż w populacji ogólnej ryzyko wystąpienia innych pozatarczycowych, wrodzonych nieprawidłowości. Nieprawidłowości te dotyczą głównie narządów i układów, w których prawidłowy rozwój i funkcjonowanie zaangażowane są geny odpowiedzialne również za prawidłowy przebieg organogenezy i syntezy hormonów gruczołu tarczowego.

Cel pracy: Ocena częstości występowania innych wad towarzyszących $\mathrm{CH}$, z uwzględnieniem możliwych przyczyn tej zależności i roli badań genetycznych.

Materiał i metody: Do badania zostały włączone 54 noworodki objęte badaniem przesiewowym w kierunku CH w latach $2010-2017$ w województwie małopolskim. Przeprowadzono dokładną retrospektywną analizę dokumentacji medycznej tych pacjentów. 
Wyniki: W grupie badanej u 20 z 54 pacjentów (37\%) stwierdzono obecność współtowarzyszących CH, wrodzonych nieprawidłowości innych narządów. U 10 (18,5\%) potwierdzono obecność wady serca, u 5 (9,25\%) stwierdzono nieprawidłowe objawy ze strony układu oddechowego, u 7 (12,96\%) stwierdzono nieprawidłowe objawy ze strony układu pokarmowego, u 5 (9,25\%) rozpoznano nieprawidłowości ze strony układu moczowo-płciowego, u 3 (5,55\%) stwierdzono nieprawidłowości ze strony układu nerwowego, u $6(11,1 \%)$ rozpoznano nieprawidłowości ze strony układu mięśniowo-szkieletowego.

Wnioski: Analiza uzyskanych danych i aktualnego piśmiennictwa wskazują, że największą rolę w powstawaniu pozatarczycowych nieprawidłowości u pacjentów z CH mogą mieć czynniki genetyczne. Zasadna wydaje się identyfikacja mutacji, która doprowadziła do $\mathrm{CH}$. Znając mutacje mogące odpowiadać za wady współtowarzyszące $\mathrm{CH}$, można by objąć pacjentów z $\mathrm{CH}$ odpowiednimi badaniami skriningowymi, mającymi na celu ich wczesne zdiagnozowanie, a w efekcie - odpowiednie, natychmiastowe leczenie.

\section{Słowa kluczowe:}

wrodzona niedoczynność tarczycy, wady wrodzone, mutacje.

\section{Introduction}

Congenital hypothyroidism $(\mathrm{CH})$ is a disease that has serious consequences in later life if not treated early during the neonatal period. The frequency of $\mathrm{CH}$ depends on the studied population; however, in the last 20-30 years an increase in frequency up to 1: 2000 newborns has been observed. The increase is caused, to a great extent, by the lowering of the thyroid-stimulating hormone (TSH) threshold value for the diagnosis $\mathrm{CH}$ in screening tests [1-4]. In Poland the frequency of $\mathrm{CH}$ is approximately $1: 3500$ newborns. This value is largely due to the implementation of measuring FT4 levels in addition to measuring TSH levels in the $3^{\text {rd }}-5^{\text {th }}$ day of life in small for gestational age newborns (lowered FT4 with lowered TSH, which is a result of an immature hypothalamo-pituitary axis) [1-3]. This is performed independently of the screening results.

Congenital hypothyroidism may be a result of improper organogenesis (morphogenesis) of the thyroid gland and occur in the form of agenesis, hemiagenesis, hypoplasia, or ectopic thyroid gland, or it can be related to improper synthesis of thyroid hormones [1]. Traditionally, it is thought that $\mathrm{CH}$ is due to improper organogenesis in $80-85 \%$ of cases, abnormalities of thyroid hormone synthesis constitute $15-20 \%$ of causes, and $5 \%$ are caused by impaired function of the pituitary gland or hypothalamus [1, 2, 4]. In accordance with data from current literature, neonates with congenital hypothyroidism have an increased rate of associated congenital defects compared to the general population (from $14.6 \%$ to 59\%) [6-8]. There are multiple factors that are thought to cause these defects to occur together. In the literature several risk factors are highlighted, such as the lack of metabolic hormones produced by the thyroid gland as well as lack of iodine in organogenesis, exposure to environmental risk factors and teratogens, consanguinity of parents, and ethnic background [6-9]. The most recent observations suggest that genetic risk factors play the most important role. According to this data, genes that are critical in the proper functioning and structure of the thyroid gland are also important in the normal functioning and structure of extrathyroidal structures [1, 2, 4-9].

In the context of these reports, it is important to consider if newborns with $\mathrm{CH}$ should have genetic testing performed with the goal of identifying the gene responsible for the occurrence of the disease. Knowing the defective gene and the gene's role in the development and function of extrathyroidal structures would help in identifying these defects earlier, before they present clinically. Patient care could be planned in advance, and late complications could be prevented.

\section{Aim of the study}

The goal of the study was to evaluate the frequency of extrathyroidal defects in $\mathrm{CH}$ patients, to review the literature on this topic, and to evaluate the role of genetic tests.

\section{Material and methods}

The study included newborns who were screened for $\mathrm{CH}$ in South-Eastern Poland in the years 2010-2017, and who, after the diagnosis of $\mathrm{CH}$, were under the medical care of our department. The $\mathrm{CH}$ screening test is based on measuring the thyroid stimulating hormone (TSH) levels in the blood from the heel of the newborn taken in the third day of life (from the $48^{\text {th }}$ hour to the seventh day after birth) using the Whatman 903 protein saver card. A TSH level $\geq 28 \mathrm{IU} / \mathrm{l}$ (in newborns born since 2012) or TSH level $\geq 35 \mathrm{IU} / \mathrm{l}$ (in newborns born before 2012) required immediate follow-up testing to verify the diagnosis of $\mathrm{CH}$. A TSH level $\geq 12 \mathrm{IU} / \mathrm{l}$ and $<28 \mathrm{IU} / \mathrm{I}$ (in newborns born since 2012) or TSH level $\geq 15 \mathrm{IU} / \mathrm{I}$ and $<35 \mathrm{IU} / \mathrm{I}$ (in newborns born before 2012) required a repeated TSH measurement from the newborn's blood, and if the level was $\geq 12 \mathrm{IU} / \mathrm{l}$ (in newborns born since 2012) or $\geq 15 \mathrm{IU} / \mathrm{I}$ (in newborns born before 2012) on the second measurement, follow-up of the newborn for $\mathrm{CH}$ was required. In Poland TSH is measured using an immunoluminometric test, which has a sensitivity of approximately $100 \%$ and specificity around $77 \%$ (which means a follow-up for 1.3 healthy children for every 1 sick child). In all newborns with a result of $\mathrm{TSH} \geq 28 \mathrm{IU} / \mathrm{l}$ or $\geq 12 \mathrm{IU} / \mathrm{l}$ and $<28 \mathrm{IU} / \mathrm{I}$ on the second measurement (in newborns born since 2012) or a result of $\mathrm{TSH} \geq 35 \mathrm{IU} / \mathrm{I}$ or $\geq 15 \mathrm{IU} / \mathrm{I}$ and $<35 \mathrm{IU} / \mathrm{I}$ on the second measurement (in newborns born before 2012), a repeated TSH as well as fT3 and fT4 in the serum of blood was performed 
Wedrychowicz A., Furtak A., Prośniak A., Żuberek M., Szczerkowska M., Pacut P., Lemańska D., Słuszniak A., Starzyk J.B.

in order to confirm the diagnosis and to begin treatment with levothyroxine. The concentration of TSH in the serum (Siemens Healthcare Diagnostics Inc., USA), fT4 (Siemens Healthcare Diagnostics Inc., USA), and fT3 (Siemens Healthcare Diagnostics Inc., USA) were marked using an immunohistochemical method. The normal ranges for each hormone were as follows: for TSH (0.5-9 ulU/ml), for fT3 (3.0-8.3 pmol/l), and for fT4 (10-25 pmol/l). In most newborns with confirmed $\mathrm{CH}$ an ultrasound was performed to evaluate the location and morphology of the thyroid gland. In 26 newborns, if there was a possibility, a Technetium 99m scintigraphy was performed. A complete history was taken and physical examination was performed for all patients. In the event of any abnormal findings on examination, patients were consulted with relevant specialists from other specialities and underwent further diagnostic lab and imaging testing if required.

\section{Results}

In the screening of newborns for $\mathrm{CH}$ in the years 2010-2017 in the Lesser Poland voivodeship, 88 newborns had a TSH level $\geq 12 \mathrm{IU} / \mathrm{I}$ (in newborns born since 2012) or $\geq 15 \mathrm{IU} / \mathrm{I}$ (in newborns born before 2012) and required further diagnostic testing. Sixty-four newborns (72.7\%) were afterward under the medical care of the Paediatric Endocrinology Clinic in Cracow. Amongst the newborns, 51 (79.6\%) had a result of $\mathrm{TSH} \geq 28 \mathrm{IU} / \mathrm{I}$ (in newborns born since 2012) or $\geq 35 \mathrm{IU} / \mathrm{l}$ (in newborns born before 2012), and 13 newborns (20.4\%) had a result of TSH $\geq 12$ and $<28 \mathrm{IU} / \mathrm{I}$ (in newborns born since 2012) or $\geq 15 \mathrm{IU} / \mathrm{l}$ and $<35 \mathrm{IU} / \mathrm{I}$ (in newborns born before 2012), which required a repeated test. On the repeated test, 11 newborns had a TSH level $\geq 12 \mathrm{IU} / \mathrm{I}$ (in newborns born since 2012) or $\geq 15 \mathrm{IU} / \mathrm{I}$ (in newborns born before 2012), and two had a TSH $<12 \mathrm{IU} / \mathrm{I}$ (in newborns born since 2012) or < 15 IU/I (in newborns born before 2012), which excluded the diagnosis of $\mathrm{CH}$. Next, in 62 newborns the levels of TSH and fT3 and fT4 were analysed to confirm the diagnosis of $\mathrm{CH}$, and five newborns had normal values, which excluded the diagnosis of $\mathrm{CH}$. In the remaining 57 newborns: the level of TSH was > $10 \mathrm{IU} / \mathrm{I}$ (mean $243.33 \mathrm{IU} / \mathrm{l}$, min. $12.56 \mathrm{IU} / \mathrm{l}$, max. > $750 \mathrm{IU} / \mathrm{l})$; the level of fT3 was mean $4.07 \mathrm{pmol} / \mathrm{l}$, min. $0.7 \mathrm{pmol} / \mathrm{l}$, and max. $7.8 \mathrm{pmol} / \mathrm{l}$; and the level of $\mathrm{fT} 4$ was mean $10.7 \mathrm{pmol} / \mathrm{l}$, min. $1.6 \mathrm{pmol} / \mathrm{l}$, and max. $25 \mathrm{pmol} / \mathrm{l}$.

From the group of 57 newborns with confirmed $\mathrm{CH}, 54$ subjects were included in the study, excluding three newborns who were born before 36 weeks of gestation. In the group of 54 newborns, 33 (61\%) were female and 21 (39\%) were male. In the studied group there was one pair of siblings from separate pregnancies; the remaining newborns were not siblings. The average duration of pregnancy was 39.35 weeks (min. 36 weeks and max. 42 weeks), average birth weight was $3335 \mathrm{~g}$ (min. $2250 \mathrm{~g}$, max. $4600 \mathrm{~g}$ ), and two newborns were small for gestational age (2250 g and $2400 \mathrm{~g}$ born in 38 and 41 weeks of gestation, respectively) according to the centile charts [10].

From the group of 54 children, an ultrasound of the thyroid gland or scintigraphy (which was performed in 26 subjects) confirmed ectopic thyroid gland in 15 (27.7\%) (sublingual in 12 patients and submandibular in three patients), dysgenesis of the thyroid gland in 5 (9.3\%), and hypoplasia of the thyroid gland in nine $(16.6 \%)$; in two $(3.7 \%)$ children dyshormonogenesis was suspected, and in the remaining 23 children (42.7\%) the form of $\mathrm{CH}$ was not determined.

In the group of 54 children, 20 (37\%) were found to have extrathyroidal defects occurring with the $\mathrm{CH}$. Among 20 children with extrathyroidal defects there were 13 girls and seven boys. Girls are more likely to have congenital heart defects (ratio of $7: 3$, respectively), respiratory system defects or breathing disturbances $(3: 2)$, gastrointestinal abnormalities $(5: 2)$, and musculosketal system abnormalities (4:2). Urogenital anomalies and abnormalities of the nervous system were found only in boys.

In the studied group of 54 children, 12 were determined to have abnormalities of the circulatory system, on the basis of a physical examination. These patients were consulted with cardiologists, who confirmed that 10 of the children (seven girls and three boys) had congenital heart defects. The most common congenital heart defects were: patent ductus arterious (PDA) in three children (30\%) and atrial septal defect (ASD) in three children (30\%) (including two who had both a PDA and ASD). The other congenital heart defects were only present in singular cases. In eight children with congenital heart defects (80\%) abnormalities of other organ systems were found, and two children (20\%) did not have any other abnormalities (Table I). The most common associated defects were those of the respiratory system, present in three of the subjects.

Five children ( 3 girls and 2 boys; 9.25\%) from the studied group presented with abnormal symptoms of the respiratory system in the form of breathing disturbances. In two of them (40\%) congenital pneumonia was diagnosed, and another two subjects (40\%) required oxygen therapy. In three children with abnormal respiratory symptoms (60\%) congenital heart defects were diagnosed (PDA, ASD, persistent foramen ovale [PFO], and hypoplastic left heart syndrome [HLHS]).

Seven children (5 girls and 2 boys; $12.96 \%$ ) from the studied group presented with gastrointestinal abnormalities. In three of them (42.85\%) an umbilical hernia was found. Other abnormalities, including tracheoesophageal fistulas, bile reflex, cleft lip and palate, and meconium plug syndrome, occurred in individual cases in the remaining four patients. Three children had co-occurrence of congenital heart defects and genitourinary defects (PDA, hydronephrosis, hydrocele).

Five children (all boys) (9.25\%) in the studied group had defects of the genitourinary system. One of them had cryptorchidism with hypospadias, and one had cryptorchidism with inguinal hernia. In 2 children (40\%) hydrocele was diagnosed, and in 1 child (20\%) hydronephrosis with urinary tract infection was diagnosed. In 3 children (60\%) gastrointestinal defects were also present (tracheoesophageal fistula and bile reflux).

Three children (all boys; 5.55\%) from the studied group were found to have abnormalities of the nervous system: developmental regression from the second year of life, epilepsy, and deafness. Two of these children also had congenital heart 
Table I. Co-occurrence of heart defects with abnormalities of other organ systems and the form of congenital hypothyroidism

\begin{tabular}{llll}
\hline Diagnosed cardiac defects & Frequency of occurrence & Other abnormalities & Form of congenital hypothyroidism \\
\hline PDA & 1 & Yes & $?$ \\
\hline ASD & 1 & Yes & Sublingual ectopic \\
\hline AvS & 1 & Yes & Agenesis \\
\hline Tetralogy of Fallot & 1 & No & Sublingual ectopic \\
\hline TAPVR & 1 & Yes & Dyshormonogenesis \\
\hline Aortic valve insufficiency & 1 & Yes & Sublingual ectopic \\
\hline PFO & 1 & Yes & Hypoplasia \\
\hline HLHS & 1 & Yes & $?$ \\
\hline PDA + ASD & 2 & Yes & $?$ \\
\hline
\end{tabular}

PDA - patent ductus arteriosus; ASD - atrial septal defect; AvS - aortic valve stenosis; TAPVR - total anomalous pulmonary venous return; PFO persistent foramen ovale; HLHS - hypoplastic left heart syndrome

defects (aortic valve stenosis [AvS] and total anomalous pulmonary venous return [TAPVR]).

Abnormalities of the musculosketal system were found in six children (4 girls and 2 boys; 11.1\%) (differences in limb length, varus and valgus deformities, decreased muscle tone, microcephaly).

Three children (2 girls and 1 boy; $5.55 \%$ ) had dermatological abnormalities. Two children had atopic dermatitis, and one had haemangioma within the skin of the abdomen. Three of the subjects (5.55\%) had abnormal blood counts with thrombocytopaenia, neutropaenia, or anaemia. One child (1.85\%) was observed to have hypoglycaemia, and one child (1.85\%) was observed to have cataracts. Trisomy 21 was diagnosed in one patient $(1.85 \%)$ on the basis of genetic testing.

In the analysed group of 20 children with $\mathrm{CH}$ and extrathyroidal defects, there was no significant relation with the level of $\mathrm{TSH}$, frequency of extrathyroidal defects, and the type of $\mathrm{CH}$ (thyroid dysgenesis or dyshormonogenesis).

\section{Discussion}

The results of the conducted study confirm the higher frequency of occurrence of extrathyroidal congenital abnormalities in newborns with $\mathrm{CH}$, compared to the general population, which has a rate of 1.82 according to the Polish Registrar of Congenital Defects. Of the 54 newborns with $\mathrm{CH}$ in the study, $20(37 \%)$ were found to have congenital defects of other organs. The results are consistent with the conclusions of other authors, which demonstrate higher occurrence of extrathyroidal defects in patients with $\mathrm{CH}$ compared to the general population. Gu et al., in their study, demonstrated co-occurrence of extrathyroidal congenital defects at a rate of 14.6\% [11]. Kreisner et al. demonstrated co-occurrence of extrathyroidal congenital defects at 13.2\% [12], Stoll et al. demonstrated 15.5\% [13], Razavi et al. showed 20\% [8], Bas et al. 28.2\% [7], and Reddy et al. up to $59 \%$ [6]. The abnormalities occur mainly in organ systems whose development and function is dependent on genes that are also responsible for proper organogenesis of the thyroid gland and thyroid hormone synthesis [1, 4, 5].

Examples of these genes are the following: NKX2-1 (known as TTF1 [thyroid transcription factor-1], homeodomain - containing a protein belonging to the NKX2 family of transcription factors); FOXE1 (known as TTF2 [thyroid transcription factor 2], forkhead box E1, a member of the forkhead/winged-helix family of transcription regulators); PAX8 (paired box gene 8, one of the PAX genes encoding a family of transcription factors); NKX2-5 (homeodomain - containing a protein belonging to the NKX2 family of transcription factors); GLIS3 (GLI-similar protein 3, a member of the GLI-similar zinc finger protein family); JAG1 (encoding Jagged-1 - ligand of the Notch receptor); TBX1 (T-box transcription factor); NTN1 (Netrin-1 gene, Laminin-related secreted protein); and CDCA8 (Cell Division Cycle-Associated protein 8 or Borealin, a component of the chromosomal passenger complex). Amongst genes that play key roles in the proper synthesis of thyroid hormones are: GNAS (Gs alpha, alpha subunit of the stimulatory guanine nucleotide-binding protein [G protein]); SLC5A5 (sodium-iodide symporter [NIS]); SLC26A4/PDS (pendrin, anion transporter); DUOX1/DUOX2 (dual oxydases, peroxide generating system); DUOXA2 (dual 
Wedrychowicz A., Furtak A., Prośniak A., Żuberek M., Szczerkowska M., Pacut P., Lemańska D., Słuszniak A., Starzyk J.B.

oxidase maturation factor 2); TPO (thyroid peroxidase); TG (thyroglobulin); and IYD/DEHAL (dehalogenase). A very important gene in the normal organogenesis process as well as thyroid hormone synthesis is the TSHR gene (TSH receptor) [4, 5].

The NKX2-1 gene demonstrates expression of the tissues of the thyroid, lungs, and prosencephalon. It plays a key role in the development of the thyroid gland and expression of genes for Tg, TPO, TSHR, and NIS. It is responsible for the differentiation of type 2 cells of the epithelium of pulmonary alveoli, expression of the genes for the surfactant protein (SP-A, SP-B, $\mathrm{SP}-\mathrm{C}$ ), and the gene ABCA3 (ABC transporter A3) involved in the transport of surfactant phospholipids and its appropriate composition. Additionally, it is important in the normal morphogenesis and functioning of the nervous system [4, 5, 14-17]. Abnormalities in the region of the NKX2-1 gene may be the cause of the syndrome called "brain-lung-thyroid syndrome". Depending on the type and size of the mutation, there may be different combinations and levels of severity of congenital hypothyroidism, and defects of the respiratory system and nervous system. The full triad occurs in approximately $30-50 \%$ of patients with the NKX2-1 gene mutation [18]. Amongst the abnormalities of the respiratory system in newborns is IRDS with variable severity, a higher frequency of infections of the upper respiratory tract, and interstitial lung disease, which is responsible for higher mortality in these patients [4, 5, 19]. Amongst the neurological defects the most typical is non-progressing choreoathetosis. However, the symptoms may not be present at birth, and they can be preceded by symptoms like hypotonia or delayed motor development at one year of age or even ADHD $[5,16]$.

The presence of respiratory and nervous system defects was noticed in our studied population of newborns with $\mathrm{CH}$. Five children (9.25) had abnormal symptoms of the respiratory system in the form of breathing disturbances (the frequency of respiratory system defects in the general population according to the Polish Registrar for Congenital Defects is $0.019 \%$ ). In three children (5.55\%) of the studied group abnormalities of the nervous system were present in the form of individual cases of developmental regression from two years of age, epilepsy, and deafness (the frequency of nervous system defects in the general population according to the Polish Registrar for Congenital Defects is $0.15 \%)$. One child was diagnosed with hypotonia and one with microcephaly. Similar data concerning $\mathrm{CH}$ and defects of the respiratory and nervous system are presented by other authors $[16,18,19]$.

Expression of the FOXE1 gene, has been detected in the thymus, pharynx, epidermis, hair follicles, and in prepubertal testes $[4,5]$. The mutation of the FOXE1 gene is associated with Bamforth-Lazarus syndrome, which can present with dysgenesis of the thyroid, cleft palate, curly hair, choanal atresia, and clefting of the epiglottis. In our studied group there was one patient $(1.85 \%)$ with cleft lip and palate (the frequency of cleft palate/lip in the general population according to the Polish Registrar for Congenital Diseases is 0.014\%). Similar data regarding the co-occurrence of these defects are mentioned by other authors. Razavi et al. found cleft lip/palate in one child
$(0.7 \%)$ out of a group of 157 subjects [8]. The association between $\mathrm{CH}$ and cleft palate in relation to a mutation in the region of the FOXE1 gene is described by Carre et al. and Castanet et al. [20, 21].

As well as playing a key role in the organogenesis of the thyroid gland, the expression of the PAX8 gene is important in the development of organs of hearing, the central nervous system, and development of the kidneys [4, 5, 9, 22, 23]. In our study five children (9.25\%) from the studied group were found to have genitourinary defects (the frequency of urinary system abnormalities in the general population according to the Polish Registrar for Congenital Diseases is $0.20 \%$, and for genital system anomalies is $0.12 \%$ ). One of the children had cryptorchidism with hypospadias, and one had cryptorchidism with an inguinal hernia. In two children (40\%) hydrocele was observed, while in one child (20\%) hydronephrosis in the presence of a urinary tract infection was found. The higher frequency of co-occurrence of genitourinary anomalies in children with $\mathrm{CH}$ has been reported by other authors, who emphasise the role of the PAX8 gene. Yousefichaijan et al. determined genitourinary anomalies in 43 out of 100 children with $\mathrm{CH}$, the most common defects being hydronephrosis and urethral stricture [22]. In another study, Yousefichaijan et al. found abnormalities in the genitourinary system in 32 out of 100 children with $\mathrm{CH}$, the most common defects being cryptorchidism and hydrocele [9]. Reports of co-occurrence of agenesis/dysgenesis of kidneys, polycystic kidney diseases like glomerulocystic disease (GCKD) and autosomal recessive kidney disease (ARPKD), and other abnormalities of the genitourinary system have been described [22-25].

Another gene that is involved in the normal organogenesis of the thyroid gland is NKX2-5 [4-6]. Expression of this gene has been determined to be involved in the proper development of the heart. The gene is particularly important in regulating the division of the heart during its morphogenesis and development and function of the atrioventricular node [26]. Foetal development of the thyroid is closely associated with the developing heart. The thyroid is pulled to the base of the neck due to the migration of the heart during the early stage of development of the thyroid. In our study, amongst 54 children with $\mathrm{CH}$, $10(18.5 \%)$ had confirmed congenital heart defects (frequency of congenital heart defects in the general population according to the Polish Registrar for Congenital Diseases is $0.70 \%$ ). The most common heart defects were PDA in three children (30\%) and ASD in three children (30\%) (including two subjects who had both PDA and ASD). The remaining heart defects were recognised in individual cases. Congenital heart defects are described in the literature as the most common extrathyroidal congenital defects in patients with $\mathrm{CH}$. Gu et al. report co-occurrence of congenital heart defects and $\mathrm{CH}$ at a level of 8.9\% [11]. Kreisner et al. report the frequency of co-occurrence at $10.5 \%$ [12], Razavi et al. report the frequency at the level of $4.9 \%$ [8], Bas et al. report the frequency at the level of $8 \%$ [7], and Reddy et al. report the frequency at the level of $29 \%$ [6]. The most common observed defects are ASD, PDA, and VSD [6-8], which is in accordance with our observations and 
confirms the role of NKX-2 gene expression in the organogenesis of the heart.

Mutations in the region of the GLIS3 gene, apart from causing defective organogenesis of the thyroid gland, may cause neonatal diabetes mellitus, congenital glaucoma, mental retardation, kidney dysplasia, progressive hepatic steatosis, and osteopaenia. According to the most recent data, mutations in the GLIS3 gene may cause deformities of fingers such as camptodactyly, syndactyly, and polydactyly as well as defects of the internal genital organs [4, 27-29]. Amongst our patients, we observed one case of psychomotor delay. In the literature there are descriptions of $\mathrm{CH}$ patients with polycystic kidney disease.

Mutations of the JAG1 gene associated with the organogenesis of the thyroid gland are the cause of many other abnormalities. The JAG1 gene is classically associated with Alagille syndrome type 1 (ALGS), which is characterised by various defects of the liver, heart, skeleton, eyes, and face [4, 27]. In the studied group, there were no Alagille syndrome patients identified. In accordance with the scientific literature, a mutation of this gene does not have to result in all the symptoms of Alagille syndrome; there can be only one symptom or even no symptoms related to this syndrome.

The TBX1 gene plays an important role in the embryogenesis of the thyroid and parathyroid glands. Mutations of this gene are related to DiGeorge syndrome, heart defects, mental retardation, immunodeficiency, facial deformities, and hypothyroidism or hypoparathyroidism.

Deletion of the gene Netrin-1 (NTN1) was described to be the cause of co-occurrence of ectopic thyroid and VSD. There appears to be a relation between the mutation of the NTN1 gene and arthrogryposis [4]. In the studied group none of the subjects presented with DiGeorge syndrome or arthrogryposis.

Genes involved with the synthesis of thyroid hormones are also important in the development and function of other structures. Mutations of the GNAS gene, as well as causing abnormalities of thyroid hormone synthesis, are causes of other defects. The mutation can cause resistance to PTH, as well as resistance to gonadotropins and gonadoliberin. Resistance to these hormones may present at varyious degrees and times [4].

The SLC5A5 gene codes for the expression of the sodium/ iodide transporter (NIS). NIS is also a membrane transporter in other tissues such as the salivary glands, lacrimal glands, mucous membranes of the small intestine, nasopharynx, thymus, ciliary bodies, skin, testicular cells, vascular plexus, lung and breast tissues, and cells in breast cancer and in the placenta [4]. Mutations causing the change of expression or function of the NIS symporter can cause a wide range of abnormalities.

The SLC26A4 gene codes a multifunctional exchanger of anions - pendrin [4, 30, 31]. In the thyroid, pendrin is expressed at the top of the thyroid membrane and allows the transport of iodine necessary for the synthesis of thyroid hormones. Expression of pendrin has been found in the inner ear and kidneys. In the inner ear pendrin functions as a chloridebicarbonate exchanger; in the kidney it participates in the secretion of bicarbonate and reabsorption of chlorides. Mutations in the region of the pendrin gene are classically associated with Pendred syndrome, defined as sensorineural hearing loss/ deafness, goitre and iodine organification defects, and hypothyroidism [4, 31]. Among our patients, one child (1.85\%) had hearing loss.

Genes DUOX 1 and DUOX 2 code for the dual oxidase system, while the genes DUOXA1 and DUOXA2 are responsible for the synthesis of hydrogen peroxide, a key phase in the production of thyroid hormone. Defects of the dual oxidase system are the most frequent cause of disturbances of iodine organification $[4,32]$.

The TSHR gene codes for the TSH receptor, which belongs to the $G$ protein-coupled receptors. According to data from previous literature, mutations of this gene may cause abnormalities in organogenesis of the thyroid gland and thyroid hormone synthesis [4, 5]. There are also data in the literature suggesting congenital heart defects and glucocorticoid deficiency in patients with $\mathrm{CH}$ due to a mutation in the TSHR gene [34].

In addition to the above abnormalities, co-accompanying congenital hypothyroidism, the formation of which can be combined with gene expression, crucial for normal organogenesis of the thyroid gland and thyroid hormone synthesis, the study also found other abnormalities. In one child (1.85\%) tracheoesophageal fistula was observed, and in another child (1.85\%) bile reflux was present. Other authors have noted the higher frequency of gastrointestinal abnormalities (the frequency of gastrointestinal defects in the general population according to the Polish Registrar for Congenital Defects is $0.093 \%$ ). Bas et al. diagnosed the presence of oesophageal atresia in two patients [7]. There are also descriptions of $\mathrm{CH}$ patients with anal atresia and Hirschsprung's disease [35, 36]. In a group 54 newborns with $\mathrm{CH}$, there were single cases of co-occurrence of the following defects: differences in limb lengths, valgus and varus deformities, haemangioma within the abdomen skin, cataracts, and trisomy 21.

Other authors mention frequent co-occurrence of $\mathrm{CH}$ and such defects as spina bifida or hip dysplasia [6, 8]. A higher frequency of ophthalmological abnormalities in patients with $\mathrm{CH}$ has been observed. Kurtul et al. described vision pathologies in $40.4 \%$ (49 of 121 ) of $\mathrm{CH}$ patients, of whom $79.5 \%$ (39 out of 49 ) had refractive errors and $32.6 \%$ (16 out of 49 ) had strabismus [37].

As demonstrated in the referenced data from the scientific literature, the increased frequency of associated congenital defects in $\mathrm{CH}$ patients compared to the general population is undisputable. The cause of increased co-occurrence of extrathyroidal defects in $\mathrm{CH}$ patients requires an in-depth analysis in order to find the underlying cause.

As mentioned in the introduction, multiple hypotheses are taken into consideration [6-9]. The cause of various extrathyroidal abnormalities in patients with $\mathrm{CH}$ is often attributed to the lack of metabolic activity of the thyroid hormone. These hormones are essential in the growth and maturity of cells and tissue in the foetal period. A lack of thyroid hormones leads to defects in the tissues of the nervous system and skeletal system, as well as other tissues [3]. This hypothesis does not appear 
to explain the co-occurrence of $\mathrm{CH}$ and defects in other organs and systems because in the first 12 weeks of life the foetus is dependent on the mother's production of thyroid hormones. At that time other organs undergo a very intensive process of organogenesis.

For example, the most common extrathyroidal defects associated with $\mathrm{CH}$ are heart defects, mostly ASD and VSD. The NKX2-5 gene appears to play an important role in these defects and is responsible for proper development of both the thyroid gland and heart [38].

The hypothesis concerning environmental factors and teratogens does not appear to be significant. For example, from the data of past literature the effect of factors such as smoking and alcohol on the urinary system is known. Yousefichaijan et al. in their study of 100 children with $\mathrm{CH}$ detected the presence of genitourinary defects in 32 children and demonstrated a lack of significance of smoking or alcohol during pregnancy on the frequency of genitourinary abnormalities [9].

The data above indicates that genetic factors may play the most important role in causing associated congenital defects in patients with $\mathrm{CH}$. As well as the genes described in this article and their role in the function and development of extrathyroidal organs, there are novel genes whose mutations may be responsible for $\mathrm{CH}$ and extrathyroidal defects. Studies based on experimental models suggest the role of the HEX homeobox gene in the development of the cardiovascular system and thyroid [6].

Our data could suggest that there is higher frequency of extrathyroidal defects in girls with $\mathrm{CH}$ in comparison to boys with

\section{References}

1. Nettore IC, Fenzi G, Macchia PE. Genetic Defects in Thyroid Hormone Supply. In: Feingold KR, Anawalt B, Boyce A, et al. (eds.). Endotext [Internet]. South Dartmouth (MA): MDText.com, Inc. 2000.

2. Kor Y, Kor D. Current status of the congenital hypothyroidism neonatal screening program in Adana Province, Turkey. J Pediatr Endocrinol Metab 2018; 31: 619-624. doi: 10.1515/jpem-2017-0433

3. Kucharska A, Beń-Skowronek I, Walczak M, et al. Congenital hypothyroidism - Polish recommendations for therapy, treatment monitoring, and screening tests in special categories of neonates with increased risk of hypothyroidism. Endokrynol Pol 2016; 67: 536-547. doi: 10.5603/EP.2016.0062

4. Persani L, Rurale G, de Filippis T, et al. Genetics and management of congenital hypothyroidism. Best Pract Res Clin Endocrinol Metab 2018; 32: 387-396. doi: 10.1016/j.beem.2018.05.002

5. Szinnai G. Genetics of normal and abnormal thyroid development in humans. Best Pract Res Clin Endocrinol Metab 2014; 28: 133150. doi: 10.1016/j.beem.2013.08.005

6. Reddy PA, Rajagopal G, Harinarayan CV, et al. High Prevalence of Associated Birth Defects in Congenital Hypothyroidism. Int J Pediatr Endocrinol 2010; 2010: 940980. doi: 10.1155/2010/940980
$\mathrm{CH}$. However, in the literature we did not find a significant relation between sex, frequency, and type of extrathyroidal defects.

\section{Conclusions}

In the context of this evidence, it appears to be beneficial to offer genetic tests to $\mathrm{CH}$ patients to identify the defective mutation that can lead to the pathological development and/ or function of the thyroid gland. Thanks to the development and improvement of genetic tests, this is realistic. Methods like Next Generation Sequencing, which allows for simultaneous and systematic sequencing of candidate genes or the whole exome (WES) or genome (WGS), can be used. Identifying the genetic risk factors would allow for an interdisciplinary approach to a patient with $\mathrm{CH}$. Knowing the associated defects in patients with $\mathrm{CH}$, we could screen them for these defects in order to achieve an early diagnosis and implement early treatment. It would have a big impact on the general development of patients with $\mathrm{CH}$ and allow for better organisation of medical care for these patients.

An advantage of our study is the analysis of a large group of patients in a time frame of seven years. A weak point of the study was the lack of information about newborns who tested positive for $\mathrm{CH}$ in our screening but received further medical care in other medical centres. We suspect that patients with associated congenital defects stayed at our multispecialty centre, which may explain the increased prevalence of these abnormalities in our studied population.

7. Baş VN, Ozgelen S, Cetinkaya S, et al. Diseases accompanying congenital hypothyroidism. J Pediatr Endocrinol Metab 2014; 27 : 485-489. doi: 10.1515/jpem-2013-0282

8. Razavi Z, Yavarikia A, Torabian S. Congenital Anomalies in Infant with Congenital Hypothyroidism. Oman Med J 2012; 27: 364-367. doi: 10.5001/omj.2012.92

9. Yousefichaijan P, Dorreh F, Sharafkhah M, et al. Congenital urogenital abnormalities in children with congenital hypothyroidism. Med J Islam Repub Iran 2017; 31: 7. doi: 10.18869/mjiri.31.7

10. Niklasson A, Albertsson-Wikland K. Continuous growth reference from 24th week of gestation to 24 months by gender. BMC Pediatr 2008; 8: 8. doi: 10.1186/1471-2431-8-8

11. Gu YH, Harada S, Kato T, et al. Increased incidence of extrathyroidal congenital malformations in Japanese patients with congenital hypothyroidism and their relationship with Down syndrome and other factors. Thyroid 2009; 19: 869-879. doi: 10.1089/thy.2008.0405

12. Kreisner E, Neto EC, Gross JL. High prevalence of extrathyroid malformations in a cohort of Brazilian patients with permanent primary congenital hypothyroidism. Thyroid 2005; 15: 165-169. doi: 10.1089/thy.2005.15.165

13. Stoll C, Dott B, Alembik Y, et al. Congenital anomalies associated with congenital hypothyroidism. Ann Genet 1999; 42: 17-20. 
14. Hermanns P, Kumorowicz-Czoch M, Grasberger H, et al. Novel Mutations in the NKX2.1 gene and the PAX8 gene in a Boy with BrainLung-Thyroid Syndrome. Exp Clin Endocrinol Diabetes 2018; 126 : 85-90. doi: 10.1055/s-0043-119875

15. Monti S, Nicoletti A, Cantasano A, et al. NKX2.1-Related Disorders: a novel mutation with mild clinical presentation. Ital J Pediatr 2015; 41: 45. doi: 10.1186/s13052-015-0150-6

16. Salerno T, Peca D, Menchini L, et al. Respiratory insufficiency in a newborn with congenital hypothyroidism due to a new mutation of TTF-1/NKX2.1 gene. Pediatr Pulmonol 2014; 49: 42-44. doi: 10. 1002/ppul.22788

17. Abu-Khudir R, Larrivee-Vanier S, Wasserman JD, et al. Disorders of thyroid morphogenesis. Best Pract Res Clin Endocrinol Metabol 2017; 31: 143-159.

18. Jovien S, Borie R, Doummar D et al. Respiratory Distress, Congenital Hypothyroidism and Hypotonia in a Newborn. Respiration 2016; 92: 188-191. doi: 10.1159/000449136

19. Carre A, Szinnai G, Castanet M, et al. Five new TTF1/NKX2.1 mutations in brain-lung-thyroid syndrome: rescue by PAX8 synergism in one case. Hum Mol Genet 2009; 18: 2266-2276. doi: 10.1093/ hmg/ddp162

20. Carré A, Hamza RT, Kariyawasam D, et al. A novel FOXE1 mutation (R73S) in Bamforth-Lazarus syndrome causing increased thyroidal gene expression. Thyroid 2014; 24: 649-654. doi: 10.1089/ thy.2013.0417.

21. Castanet M, Park SM, Smith A, et al. A novel loss-of-function mutation in TTF-2 is associated with congenital hypothyroidism, thyroid agenesis and cleft palate. Hum Mol Genet 2002; 11: 2051-2059.

22. Yousefichaijan P, Dorreh F, Rafeie M, et al. Congenital anomalies of kidney and upper urinary tract in children with congenital hypothyroidism; a case-control study. J Renal Inj Prev 2015; 4: 120-126. doi: 10.12861/jrip.2015.26

23. Ramos HE, Carré A, Chevrier L, et al. Extreme phenotypic variability of thyroid dysgenesis in six new cases of congenital hypothyroidism due to PAX8 gene loss-of-function mutations. Eur J Endocrinol 2014; 171: 499-507. doi: 10.1530/EJE-13-1006

24. Satomura K, Michigami T, Yamamoto K, et al. A case report of glomerulocystic kidney disease with hypothyroidism in a newborn. Nihon Jinzo Gakkai Shi 1998; 40: 602-606.

25. Jeha GS, Tatevian N, Heptulla RA. Congenital hypothyroidism in association with Caroli's disease and autosomal recessive po- lycystic kidney disease: patient report. J Pediatr Endocrinol Metab 2005; 18: 315-318

26. Schott JJ, Benson DW, Basson CT, et al. Congenital heart disease caused by mutations in the transcription factor NKX2-5. Science 1998; 281: 108-111.

27. Cherella CE, Wassner AJ. Congenital hypothyroidism: insights into pathogenesis and treatment. Int J Pediatr Endocrinol 2017; 2017: 11. doi: 10.1186/s13633-017-0051-0

28. Dimitri P. The role of GLIS3 in thyroid disease as part of a multisystem disorder. Best Pract Res Clin Endocrinol Metabol 2017; 31: 175-182.

29. Fu C, Luo S, Long X, et al. Mutation screening of the GLIS3 gene in a cohort of 592 Chinese patients with congenital hypothyroidism. Clin Chim Acta 2018; 476: 38-43. doi: 10.1016/j.cca.2017.11.011.

30. Mantovani G, Elli FM, Corbetta S. Hypothyroidism associated with parathyroid disorders. Best Pract Res Clin Endocrinol Metabol 2017; 31: 161-173

31. Wemeau JL, Kopp P. Pendred syndrome. Best Pract Res Clin Endocrinol Metabol 2017; 31: 213-224.

32. Zamproni I, Grasberger H, Cortinovis F, et al. Biallelic inactivation of the dual oxidase maturation factor 2 (DUOXA2) gene as a novel cause of congenital hypothyroidism. J Clin Endocrinol Metabol 2008; 93: 605-610.

33. Cangul H, Bas VN, Saglam Y, et al. A nonsense thyrotropin receptor gene mutation (R609X) is associated with congenital hypothyroidism and heart defects. J Pediatr Endocrinol Metab 2014; 27 : 1101-1105. doi: 10.1515/jpem-2014-0025.

34. Tiosano D, Pannain S, Vassart G, et al. The hypothyroidism in an inbred kindred with congenital thyroid hormone and glucocorticoid deficiency is due to a mutation producing a truncated thyrotropin receptor. Thyroid 1999; 9: 887-894.

35. Mehmetoğlu F. Rectal Atresia and Congenital Hypothyroidism: An Association or Coincidence? European J Pediatr Surg Rep 2018; 6 : 7-10. doi: 10.1055/s-0037-1612610.

36. Kota SK, Modi KD, Rao MM. Hirschsprung's Disease with Congenital Hypothyroidism. Indian Pediatr 2012; 49: 245-246.

37. Kurtul BE, Ozer PA, Kabatas EU, et al. Ophthalmic Manifestations in Children With Congenital Hypothyroidism. J Pediatr Ophthalmol Strabismus 2016; 53: 29-34. doi: 10.3928/01913913-20160113-06

38. Benson DW, Silberbach GM, Kavanaugh-McHugh A, et al. Mutations in the cardiac transcription factor NKX2.5 affect diverse cardiac developmental pathways. J Clin Invest 1999; 104: 1567-1573. 